\title{
Article
}

\section{Dual Targeting Oncoproteins MYC and HIF1 $\alpha$ Regresses Tumor Growth of Lung Cancer and Lymphoma}

\author{
Xiaohu Huang ${ }^{1, * \mathbb{D}}$, Yan Liu ${ }^{2}$, Yin Wang ${ }^{2}$, Christopher Bailey ${ }^{2}$, Pan Zheng ${ }^{2,3,4}$ and Yang Liu ${ }^{2,3,4, *}$ \\ 1 Division of Endocrinology, Diabetes and Nutrition, Department of Medicine, \\ University of Maryland School of Medicine, Baltimore, MD 21201, USA \\ 2 Division of Immunotherapy, University of Maryland Baltimore School of Medicine, \\ Baltimore, MD 21201, USA; yanliu@ihv.umaryland.edu (Y.L.); yin.wang@ihv.umaryland.edu (Y.W.); \\ chris.bailey@ihv.umaryland.edu (C.B.); pzheng@ihv.umaryland.edu (P.Z.) \\ 3 Department of Surgery, University of Maryland Baltimore School of Medicine, Baltimore, MD 21201, USA \\ 4 OncoImmune, Inc., Rockville, MD 20850, USA \\ * Correspondence: xiaohu.huang@som.umaryland.edu (X.H.); yaliu@ihv.umaryland.edu (Y.L.)
}

Citation: Huang, X.; Liu, Y.; Wang, Y.; Bailey, C.; Zheng, P.; Liu, Y. Dual Targeting Oncoproteins MYC and HIF1 $\alpha$ Regresses Tumor Growth of Lung Cancer and Lymphoma. Cancers 2021, 13, 694. https://doi.org/ 10.3390/cancers13040694

Academic Editor: Claire Dubois

Received: 6 January 2021

Accepted: 5 February 2021

Published: 9 February 2021

Publisher's Note: MDPI stays neutral with regard to jurisdictional claims in published maps and institutional affiliations.

Copyright: (c) 2021 by the authors. Licensee MDPI, Basel, Switzerland. This article is an open access article distributed under the terms and conditions of the Creative Commons Attribution (CC BY) license (https:// creativecommons.org/licenses/by/ $4.0 /)$.
Simple Summary: Both MYC and HIF1 $\alpha$ are critical transcriptional factors involved in the initiation, transformation, progression and maintenance in a variety of human tumors, but till now no study indicates whether it is possible to simultaneously targeting both MYC and HIF1 $\alpha$ for therapeutics. Here we report that echinomycin simultaneously inhibited MYC and HIF1 $\alpha$ through proteasomal degradation. Treatment of echinomycin regressed tumor cell growth both in vitro cultured cells and in vivo mouse models of lung cancer and lymphoma. $\beta$-TrCP and VHL are involved in the degradation of MYC and HIF1 $\alpha$ induced by echinomycin, respectively. Our data provided a new approach to target these and potentially other oncogenic proteins for cancer therapy.

Abstract: MYC and HIF1 $\alpha$ are among the most important oncoproteins whose pharmacologic inhibition has been challenging for the diverse mechanisms driving their abnormal expression and because of the challenge in blocking protein-DNA interactions. Surprisingly, we found that MYC and HIF1 $\alpha$ proteins in echinomycin-treated cells were degraded through proteasome dependent pathways, respectively by the $\beta$-TrCP- or VHL-dependent mechanisms. The degradation is induced in a variety of cancer types, including those with mutations in the p53 tumor and LKB tumor suppressors and the KRAS oncogene. Consistent with inhibition of MYC and HIF1 $\alpha$, administration of echinomycin inhibited growth of lung adenocarcinoma xenograft and a syngeneic lymphoma model in mice. Furthermore, echinomycin efficiently induced regression of syngeneic mouse lymphoma driven by MYC over-expression. Our data demonstrated a new mechanism by which echinomycin simultaneously targets MYC and HIF1 $\alpha$ for degradation to inhibit growth of lung cancer and lymphoma. Given the broad impact of $\beta$-TrCP or VHL in stability of oncogenic proteins, echinomycin may emerge as a non-PROTAC (proteolysis targeting chimera) degrader of oncogenic proteins.

Keywords: MYC; HIF1 $\alpha$; protein degradation; proteasome; lung cancer; lymphoma

\section{Introduction}

Cancer usually results from alterations of oncogenes and tumor suppressor genes, which are often mutated and/or abnormally expressed during tumorigenesis. Among them, MYC is one of the most potent and commonly activated oncogenes, which was mainly amplified or overexpressed in a broad range of human cancers [1]. MYC is a basic helix-loop-helix leucine zipper (bHLH-LZ) transcription factor regulating the expression of $10-15 \%$ of all genes of the genome [2-4]. Nuclear MYC heterodimerizes with MAX and then binds to a specific DNA sequence (E-box) to regulate different biological activities of tumor cells, including cell proliferation, growth, metabolism and metastasis [5]. MYC activation is thus considered as a hallmark of cancer initiation and maintenance [6]. Dysregulation of 
MYC occurs in $30-40 \%$ of human cancers, including both solid tumors and hematological malignancies, such as breast, colon, lung cancer, melanoma and myeloid leukemias [7,8]. Due to the difficulty to pharmacologically target MYC, it has been considered as an "undruggable" target in cancer therapy [9].

Hypoxia-inducible factor-1 (HIF1) is a master regulator mediating response to hypoxic stress in both normal tissues and tumors. It consists of a constitutively expressed HIF1 $\beta$ subunit and an oxygen-responsive HIF1 $\alpha$ subunit, whose levels are tightly controlled. HIF1 $\alpha$ has a very short half-life under normal oxygenated condition in normal cells [10]. Rapid degradation is mediated through von Hippel-Lindau tumor suppressor protein (VHL) which is a recognition subunit of E3 ubiquitin ligase followed by degradation through $26 \mathrm{~S}$ proteasome [11]. In a hypoxic environment and in cells undergoing oncogenic transformation, HIF1 $\alpha$ is stabilized $[12,13]$ and binds to hypoxia response element (HRE) to regulate the expression of target genes. HIF1 $\alpha$ is also stabilized in cancers under normoxia, presumably due to dysregulation of its degradation pathway. A tight association between HIF1 $\alpha$ expression and poor prognosis and survival has been reported in different cancers including colorectal cancer, non-small-cell lung cancer (NSCLC) and pancreatic ductal adenocarcinomas patients [14-16]. Therefore, targeting HIF1 $\alpha$ is of great importance to regress and inhibit the growth of tumors [17].

MYC targeting has been focused on transcriptional repression of the gene, primarily through bromine domain inhibitors [18,19]. In targeting its binding to cellular DNA, protein folding as well as translation and degradation, a number of HIF1 $\alpha$ inhibitors have been reported [17]. Despite the intensive interests, MYC and HIF1 $\alpha$ have not been successfully targeted for clinical cancer treatment.

Both MYC and HIF1 $\alpha$ are nuclear transcription factors and are involved in the progress and maintenance of tumors. Recent studies revealed that dysregulated MYC can cooperate with HIF1 $\alpha$ to promote tumorigenesis through induction of glycolytic metabolism and angiogenesis [20]. In addition, high basal MYC and HIF1 $\alpha$ levels were observed in all multiple myeloma (MM) cell lines and primary MM cells where MYC collaborates with HIF1 $\alpha$ to trigger VEGF production and induction of MM angiogenesis [21]. Furthermore, stabilization of HIF1 $\alpha$ and up-regulation of MYC have been revealed in central nervous system primitive neuroectodermal tumors (CNS-PNET) animal model [22]. Therefore, concurrent targeting MYC and HIF1 $\alpha$ may represent a better, more effective way for cancer with high expression of MYC and/or HIF1 $\alpha$.

In order to explore the possibility of simultaneous targeting of MYC and HIF1 $\alpha$, we revisited an early study which suggested that echinomycin may target transcriptional activity of both MYC and HIF1 $\alpha[23,24]$. Surprisingly, we observed that, rather than transcriptional repression, echinomycin induces proteasomal degradation of both MYC and HIF1 $\alpha$, respectively through transcriptional regulation of $\beta$-TrCP or VHL expression. Our data revealed echinomycin as a new type of oncoprotein degrader with potentially broad application for cancer therapy.

\section{Materials and Methods}

\subsection{Cell Culture}

Lung cancer cell lines (NCI-H1944, NCI-H727, Calu-1) were obtained from the American Type Culture Collection (ATCC, Gaithersburg, MD, USA). NCI-H1944, NCI-H727 and A549 were maintained in RPMI-1640 medium supplemented with 10\% fetal bovine serum (FBS). Calu-1 cells were cultured in ATCC-formulated McCoy's 5a. E $\mu$-Myc lymphoma cells were kindly provided by Drs. Ricky W. Johnstone and Leigh Ellis. These lymphoma cells were cultured in high glucose Dulbecco's modified Eagle's medium (DMEM) supplemented with $10 \%$ fetal calf serum, penicillin/streptomycin, $0.1 \mathrm{mM} \mathrm{L}$-asparagine and $50 \mu \mathrm{M}$ 2-mercaptoethanol in a $37^{\circ} \mathrm{C}, 10 \% \mathrm{CO}_{2}$ humidified incubator. 


\subsection{Cell Proliferation Assay}

Cell proliferation was analyzed using Cell Proliferation Kit I (MTT) (Sigma, Burlington, MA, USA). And procedures were performed according to the instruction from manufacture. Briefly, cells were seeded at a concentration of $5 \times 10^{4}$ cells/well in 96-well plate, and then cells were treated with vehicle or echinomycin at different concentrations for $48 \mathrm{~h}$ followed by adding $10 \mu \mathrm{L}$ MTT per well. The plate was incubated at $37^{\circ} \mathrm{C}$ for $4 \mathrm{~h}$ in a humidified incubator. $100 \mu \mathrm{L}$ of the solubilization solution was added into each well and the plate was kept at $37^{\circ} \mathrm{C}$ overnight. Then measurement was performed at $570 \mathrm{~nm}$ on a photo spectrometer (Synergy H4 Hybrid Reader, BioTek, Winooski, VT, USA) with the reference wavelength at $690 \mathrm{~nm}$.

\subsection{Gene Editing of vhl by CRISPR}

Cultured H1944 cells in 6-well plate were infected with VHL sgRNA CRISPR All-inOne Lentivirus (Human) (Applied Biological Materials Inc., Richmond, BC, Canada ), and then infected cells were selected with puromycin $(2 \mu \mathrm{g} / \mathrm{mL})$. Single clones were picked and analyzed by sequencing (both genomic DNA and cDNA) and western blot. Genomic regions flanking the $v h l$ gene-editing site were PCR amplified using PrimeSTAR HS DNA Polymerase (Takara, Mountain View, CA, USA) and PCR purified using a QIAquick PCR Purification Kit (QIAGEN, Hilden, Germany) followed by sequencing. For the transcript analysis, RNAs were isolated using the Trizol method (Invitrogen, Carlsbad, CA, USA) and were transcribed into cDNA using SuperScript ${ }^{\circledR}$ III First-Strand Synthesis System (Thermo Fisher Scientific, Waltham, MA, USA). Then, the sequence spanning the whole vhl cDNA was amplified by PCR and purified using QIAquick PCR Purification Kit (QIAGEN) or a QIAquick Gel Extraction Kit (QIAGEN). Purified products were either sequenced directly or sequenced after being cloned into pCMV6-Entry vector through In-Fusion ${ }^{\circledR}$ HD Cloning Kit (Clontech, Mountain View, CA, USA).

\subsection{Colony Formation Assay}

$5 \times 10^{4}$ cells were seeded in each well in 6-well plate. After 3 weeks in culture, the cells were then treated with vehicle or echinomycin at different concentrations for $48 \mathrm{~h}$. Medium was changed with fixing/staining solution $(0.05 \%(w / v)$ crystal violet, $1 \%$ formaldehyde, $1 \%$ methanol in PBS buffer). Cells were stained for $20 \mathrm{~min}$ at room temperature. Plate was washed by water and air dried. The colonies were either photographed or counted. The total number of colonies ( $>50$ cells) per well was counted using a microscope.

\subsection{Western Blotting}

Whole-cell lysates were prepared in RIPA buffer (Thermo Fisher Scientific, Bedford, MA, USA) supplemented with phosphatase (Sigma Aldrich, St. Louis, MO, USA) and protease inhibitors (Roche, Brighton, MA, USA). Protein quantification was performed with the BCA Protein Assay kit (Pierce, Waltham, MA, USA) and $20 \mu \mathrm{g}$ of protein was loaded in NuPAGE 4-12\% Bis-Tris Protein Gels (Invitrogen). Then, proteins were transferred onto nitrocellulose or polyvinylidene fluoride (PVDF) membranes. After $1 \mathrm{~h}$ blocking at room temperature using $5 \%$ blocking milk in phosphate -buffered saline solution $/ 0.1 \%$ Tween (PBST), membranes were incubated overnight with primary antibody in $2.5 \%$ milk in PBST at $4{ }^{\circ} \mathrm{C}$. After the incubation, membranes were washed three times in PBST and incubated with secondary antibody for $1 \mathrm{~h}$ at room temperature with shaking. After three-time washing in PBST, membranes were developed using regular ECL Western Blotting Substrate or SuperSignal ${ }^{\mathrm{TM}}$ West Femto Maximum Sensitivity Substrate (Pierce) and visualized using the film processor (SRX-101A, Konica, Wayne, NJ, USA). Quantification of Western blots was done using the Image J software (NIH, Bethesda, MD, USA). For stripping, membrane was vigorously shaken in Restore ${ }^{\mathrm{TM}}$ PLUS Western Blot Stripping Buffer (Thermo Fisher Scientific) for $10 \mathrm{~min}$. After stripping, membrane was washed three times in PBST followed by regular immunoblotting process. The following primary antibodies were used for 
western blotting: MYC (D84C12, Cell Signaling Technology); HIF1 $\alpha$ (GTX127309, GeneTex Inc., Irvine, CA, USA); $\beta$-ACTIN (MABT825, EMD Millipore, Burlington, MA, USA).

\subsection{Quantitative RT-PCR}

RNA was isolated using the Trizol method (Invitrogen) and was transcribed into cDNA using SuperScript ${ }^{\circledR}$ III First-Strand Synthesis System (Thermo Fisher Scientific) or All-In-One RT MasterMix (Applied Biological Materials Inc., Richmond, BC, Canada). Quantitative RT-PCR (qRT-PCR) was performed by real-time analysis using Power SYBR Green PCR Master Mix (Applied Biosystems, Foster City, CA, USA) or SYBR Green qPCR Master Mix (Low ROX) (Bimake, Houston, TX, USA). Actin and GAPDH were used as internal control for human derived cells and mouse derived cells, separately. Sequences of primers are shown in Table S1.

\subsection{Electrophoretic Mobility Shift Assay (EMSA)}

LightShift ${ }^{\mathrm{TM}}$ Chemiluminescent EMSA kit (20148, Thermo Scientific) was used to assess the DNA binding ability of MYC and Hif1 $\alpha$. The assay was performed according to manufacturer's protocol. Active recombinant c-Myc protein (31117) and Max protein (31244) were purchased from Active Motif (Carlsbad, CA, USA). Active c-Myc and Max protein $(0.25 \mu \mathrm{g} / \mathrm{each}$ protein) was mixed with $50 \%$ Glycerol, $15 \mathrm{ng} / \mu \mathrm{L}$ Poly ( $\mathrm{d} \bullet \bullet \mathrm{dC})$, annealed Biotin end-labeled E-box DNA (20fmol) (5'-CGGAAGCAGACCACGTGGTCTGCTTCC-3') [25] and then incubated with echinomycin for $10 \mathrm{~min}$ at room temperature. The DNA-protein complexes were then separated from free probes by electrophoresis on a $6 \%$ polyacrylamide gel in $0.5 \times \mathrm{TBE}$, and subsequently transferred onto Biodyne B Nylon Membrane (77016, Thermo Scientific). Transferred DNA was crosslinked to membrane using UV Stratalinker 2400 (Stratagene, San Diego, CA, USA). Biotin-labeled DNA was detected by chemiluminescence according to the standard instructions provided by the manufacturer.

\subsection{Apoptosis Assays}

To quantitate apoptotic cell death, cells were collected by trypsinization, washed with phosphate buffered saline and stained using the Annexin V and PI (BD Pharmingen, San Diego, CA, USA). Fluorescence was detected by flow cytometry (BD CANTO II) and analyzed using the FlowJo software. Total events $(20,000)$ were collected and then subsequently analyzed for the percentage of Annexin $\mathrm{V}$ positive cells.

\subsection{Nuclear Fractionation}

Nuclear fractionation was carried out as previously reported [26] with some modifications. To isolate chromatin, cells were resuspended in buffer A (10 mM HEPES, [pH 7.9], $10 \mathrm{mM} \mathrm{KCl}, 1.5 \mathrm{mM} \mathrm{MgCl}, 0.34 \mathrm{M}$ sucrose, $10 \%$ glycerol, phosphatase and protease inhibitors). Triton X-100 (0.1\%) was added, and the cells were incubated for 5-8 min on ice. Nuclei were collected by low-speed centrifugation $\left(5 \mathrm{~min}, 1300 \times \mathrm{g}, 4^{\circ} \mathrm{C}\right)$. The supernatant was further clarified by high-speed centrifugation $\left(10 \mathrm{~min}, 20,000 \times \mathrm{g}, 4^{\circ} \mathrm{C}\right)$ to remove cell debris and insoluble aggregates, and this fraction was saved as cytosolic fraction. Nuclei were washed once in buffer A, and then lysed in buffer B ( 3 mM EDTA, 0.2 mM EGTA, phosphatase and protease inhibitors) for $30 \mathrm{~min}$ on ice. Insoluble chromatin was collected by centrifugation $\left(5 \mathrm{~min}, 1700 \times \mathrm{g}, 4^{\circ} \mathrm{C}\right)$, washed once in buffer $\mathrm{B}$, and centrifuged again under the same conditions. The supernatant was saved as nucleoplasmic fraction. The final chromatin pellet was resuspended in RIPA plus $0.5 \%$ SDS lysis buffer and sonicated for $60 \mathrm{~s}$ with $15 \mathrm{~s}$ intervals for four cycles in a sonicator using a microtip at $25 \%$ amplitude.

\subsection{Protein Degradation and $m R N A$ Stability Analysis}

To check the protein degradation of MYC and HIF1 $\alpha$, H1944 cells were treated with echinomycin ( $8 \mathrm{nM})$, MG132 (5 $\mu \mathrm{M})$, echinomycin plus MG132 or echinomycin $(8 \mathrm{nM})$, cycloheximide $(25 \mu \mathrm{g} / \mathrm{mL})$, echinomycin plus cycloheximide for indicated time points in the figures. Subsequently, protein levels were determined via immunoblotting. For mRNA 
stability determination, $\mathrm{H} 1944$ cells were co-incubated with Actinomycin D (ActD, $5 \mu \mathrm{M})$ and vehicle or echinomycin for various time points as indicated in the figures. RNAs were collected using the Trizol method and quantified by qRT-PCR.

\subsection{Xenogeneic Animal Studies}

All mouse experiments were conducted in accordance with standards of animal care and approved by the Children's National Medical Center (CNMC) Animal Care and Use Committee. Female 6- to 8-week-old Athymic NCr-nu/nu mice (Charles River Laboratories, Frederick, MD, USA) were used for animal experiments with H1944 cellsderived xenografts, and maintained under pathogen-free conditions. Cells were thawed from liquid nitrogen and recovered for $48 \mathrm{~h}$. One flank of these nude mice was injected subcutaneously per mouse with recovered H1944 cells $\left(1 \times 10^{6}\right)$. After inoculation, mice were weighed and tumors were measured by calliper every 3 days. Tumor volume was calculated using the following formula: tumor volume $=\left(L \times W^{2}\right) \times 0.52$, in which $\mathrm{L}$ and $\mathrm{W}$ refer to the long and short tumor diameter, respectively. Mice were randomized into vehicle group and echinomycin treated group according to tumor volume. Six days after cell inoculation (diameter of tumors is around $2.5 \mathrm{~mm}$ ), mice received $30 \mu \mathrm{L}$ vehicle or liposome formulated echinomycin $(0.14 \mu \mathrm{g} / \mu \mathrm{L})$ by subcutaneous injection $(200 \mu \mathrm{g} / \mathrm{kg})$. The injection was repeated once 1 week after the first injection. No obvious toxicities were observed in the vehicle- or drug-treated animals as assessed by the change of body weight between vehicle- and drug-treated mice. All the mice in the vehicle- and echinomycin-treated groups were euthanized and tumors were taken out for the measurement of tumor weight.

\subsection{Transfection and In Vivo Transplantation}

E $\mu$-Myc B-cell lymphoma cells were kindly provided by Drs. Ricky W. Johnstone

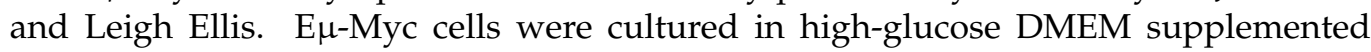
with $10 \%$ fetal bovine serum, penicillin/streptomycin, $0.1 \mathrm{mML}$-asparagine and $50 \mu \mathrm{M}$ 2-mercaptoethanol in a $37{ }^{\circ} \mathrm{C}, 10 \% \mathrm{CO}_{2}$ humidified incubator [27]. E $\mu$-Myc cells were infected with firefly luciferase (FLuc)-F2A-GFP-IRES-Puro lentivirus (Biosettia, San Diego, CA, USA) and sorted using flow cytometry after selecting by puromycin.

For in vivo study, C57BL/ 6 male mice (6-8 weeks old) were injected (intravenous, tail vein) with $2 \times 10^{6}$ E $\mu$-myc lymphoma cells expressing GFP. Echinomycin $(100 \mu \mathrm{g} / \mathrm{kg})$ or PBS (vehicle control) was injected (intravenous) every other day for 5 times. Whole blood $(20-30 \mu \mathrm{L})$ was drawn from each mouse at indicated time points. Following lysis of red blood cells by ammonium-chloride-potassium (ACK) lysing buffer, GFP positive cells (lymphoma) were measured by flow cytometry (BD FACSCanto II) after staining with CD45 antibody for $20 \mathrm{~min}$ and analyzed using FlowJo software (version 7.6.1, Ashland, OR, USA).

\subsection{Statistics}

Statistical data are expressed as mean \pm SEM and Student's $t$-test was used to determine the significance of the difference. Kaplan-Meier analysis was performed and comparisons were done using the log-rank (Mantel-Cox) test. A p-value $<0.05$ was considered statistically significant.

\section{Results}

\subsection{Echinomycin Induces Degradation of MYC and HIF1 $\alpha$ Proteins}

It is assumed that HIF1 $\alpha$ regulates gene expression by binding to core DNA sequence $5^{\prime}$-ACGTG-3' within the hypoxia response element (HRE) of target gene promoters. Although echinomycin inhibits DNA-binding activity to HRE, $\mathrm{IC}_{50}$ for HRE binding (>40 nM) was significantly higher than $\mathrm{EC}_{50}$ in reporter assay [23]. These data raised the intriguing possibility that biological activities of echinomycin may be at least partially independent of blocking HIF1 $\alpha$ binding to HRE. As shown in Figure S1A, the MYC E-box motif is very similar to that of HRE. While echinomycin was known to block MYC reporter activity, its 
effect on MYC binding to MYC (E-box) (5'-CACGTG-3') has not been evaluated. To fill in this gap, we performed electrophoretic mobility shift assay (EMSA) to test whether the effect of echinomycin on MYC binding to E-box explained its effect on MYC transcription activity. Figure S1B showed echinomycin inhibited MYC DNA-binding activity in a dose-dependent fashion from $4 \mathrm{nM}$ to $400 \mathrm{nM}$, with an $\mathrm{IC}_{50}$ of about $40 \mathrm{nM}$.

To measure efficacy of echinomycin on MYC or HIF1 $\alpha$ transcriptional activity, HEK293 cells were transiently transfected with cDNA encoding MYC or mutant HIF1 $\alpha$ (P402A/P564A) in conjunction with either E-box-driven or HRE-driven EGFP reporter, and the transfected cells were treated with vehicle or $4 \mathrm{nM}$ echinomycin at the same time. At $24 \mathrm{~h}$ after transfection, flow cytometry analysis showed $13.7 \pm 0.85 \%$ and $21.7 \pm 0.92 \%$ cells were $\mathrm{GFP}^{+}$respectively in MYC plus E-box-GFP or HIF1 $\alpha$ plus HRE-GFP transfected cells. However, $\mathrm{GFP}^{+}$cells decreased to $1.61 \pm 0.10 \%$ and $2.25 \pm 0.12 \%$ in MYC plus E-boxGFP and HIF1 $\alpha$ plus HRE-GFP transfected cells, separately, upon echinomycin treatment (Figure S1C). Therefore, $\mathrm{EC}_{50}$ for transcriptional activities of both HIF1 $\alpha$ and MYC are well below $4 \mathrm{nM}$. These data raised the intriguing possibility that echinomycin may inhibit both HIF1 $\alpha$ and MYC activities by mechanisms other than blocking their binding to DNA.

To substantiate this observation, the non-small cell lung cancer (NSCLC) cells H1944 were treated with various concentrations of echinomycin, and cell viability was assessed by MTT assay after $48 \mathrm{~h}$. The concentration of echinomycin resulting in $50 \%$ cell death $\left(\mathrm{IC}_{50}\right)$ was $3.9 \pm 1.1 \mathrm{nM}$ in this assay (Figure S2A). In addition, we further checked the effect of echinomycin on the survival and proliferation of H1944 cells using clonogenic assay (Figure S2B). A significant reduction in H1944 cell growth was observed by echinomycin treatment from 2 to $8 \mathrm{nM}$. And apoptotic cells labeled by annexin $V$ increased after treatment by $4 \mathrm{nM}$ echinomycin for $48 \mathrm{~h}$ (Figure S2C). These data indicated that echinomycin can effectively inhibit cell growth and induce apoptosis of NSCLCs and the $\mathrm{EC}_{50}$ is well below $\mathrm{IC}_{50}$ measured by DNA-binding assays.

In our effort to identify mechanisms for echinomycin pharmacological effect in repressing MYC and HIF1 $\alpha$ function, we found echinomycin decreased HIF1 $\alpha$ protein in a dose dependent manner from 1 to $8 \mathrm{nM}$ in $\mathrm{H} 1944$ cells when they were treated for $24 \mathrm{~h}$ (Figure 1A). We also found MYC oncoprotein showed almost the same trend as HIF1 $\alpha$ that echinomycin effectively diminished its protein level (Figure 1A,C). Figure 1B further showed a time dependent decrease of HIF1 $\alpha$ and MYC proteins from 0 to $24 \mathrm{~h}$ by echinomycin at the concentration of $4 \mathrm{nM}$.

We explored whether this regulation occurs at transcriptional or posttranscriptional levels. Our data demonstrated that mRNAs of both myc and hif $1 \alpha$ were paradoxically increased after echinomycin treatment in dose- and time-dependent manners (Figure 1C). This is substantiated with multiple primer pairs for myc and hif1 $\alpha$ spanning exon-exon junctions (Figure S3).

To substantiate this finding, we exploited another lung cancer cell line H727, two breast cancer cells BT474 and MDA-MB-231, lymphoma and leukemia cell lines E $\mu-\mathrm{Myc}$ and THP1. As shown in Figure S4A-C, the protein contents of both MYC and HIF1 $\alpha$ were consistently decreased upon the treatment of echinomycin for $24 \mathrm{~h}$ in lung and breast cancer cell lines. In addition, echinomycin decreased MYC and HIF1 $\alpha$ protein levels in leukemia cell line THP1 (Figure S4D) from hematologic malignancies as well. Therefore, echinomycin broadly inhibited MYC and HIF1 $\alpha$ function via diminishing their protein level at higher efficacy than inhibiting their DNA binding ability. Consistent with reduction of MYC and HIF1 $\alpha$ protein levels, the expression of MYC and HIF1 $\alpha$ target genes, including tert, brca1, ldha and glut1, decreased upon echinomycin treatment (Figure 1D). Taken together, these data showed that, echinomycin reduced protein levels of MYC and HIF1 $\alpha$ in spite of the increased mRNAs after treatment. 


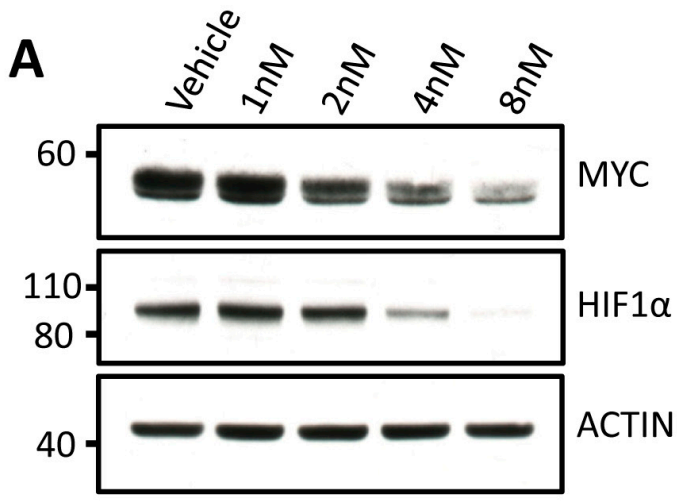

B
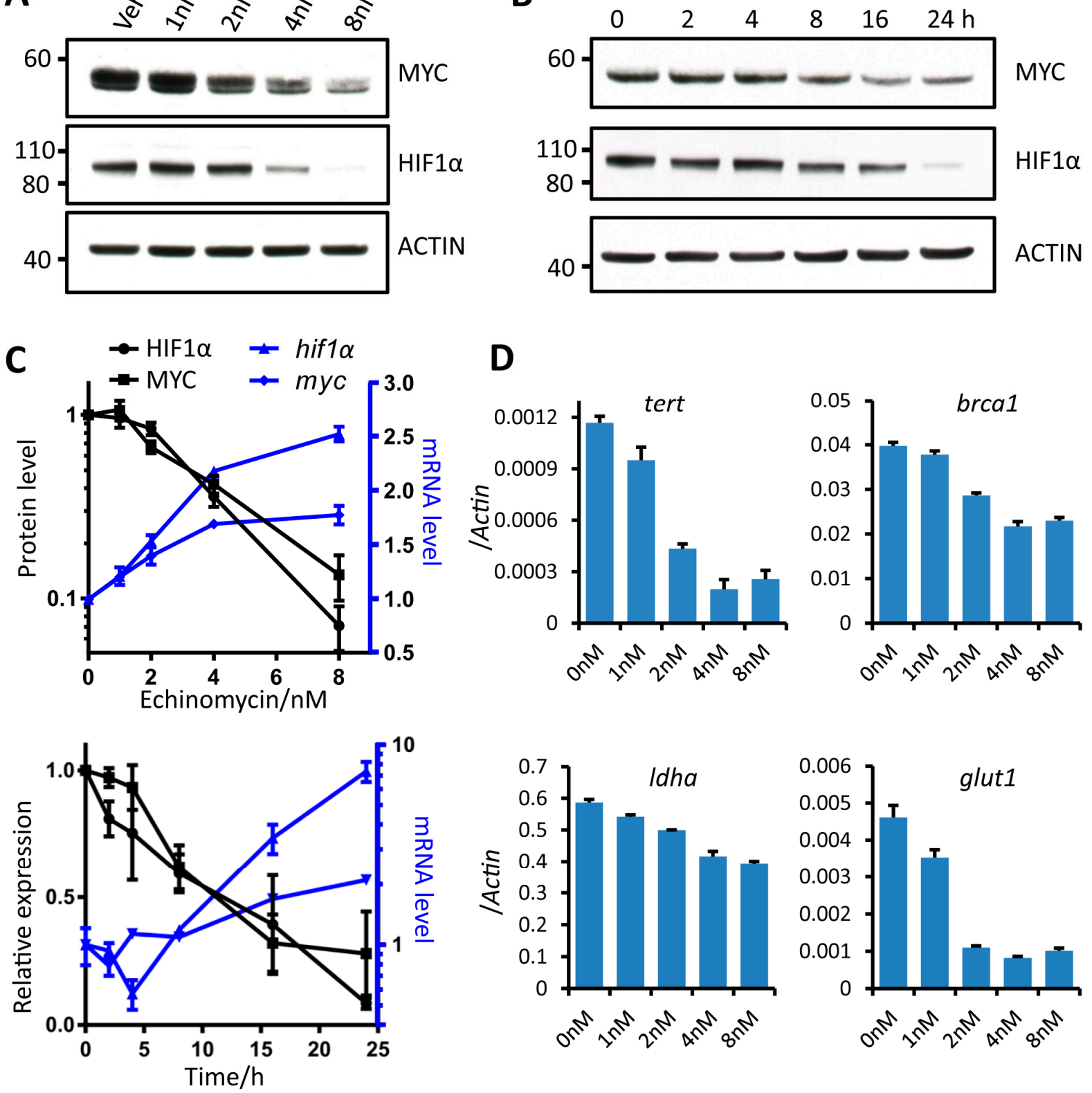

Figure 1. Echinomycin reduced MYC and HIF1 $\alpha$ proteins but increased their mRNAs. (A) Western blot analysis of MYC and HIF1 $\alpha$ proteins in H1944 lung adenocarcinoma cells treated with echinomycin at indicated concentrations for $24 \mathrm{~h}$. Experiments were repeated 4 times. The uncropped Western blots have been shown in Figure S14. (B) Timedependent decrease of MYC and HIF1 $\alpha$ proteins in H1944 cells treated with $4 \mathrm{nM}$ echinomycin at indicated time points. Experiments were repeated 3 times. (C) Quantification of MYC and HIF1 $\alpha$ protein levels ( $n=4$ replicates) and $m y c$ and $h i f 1 \alpha$ RNAs in H1944 lung adenocarcinoma cells treated for $24 \mathrm{~h}$ with echinomycin at indicated concentrations (upper panel) ( $n=3$ replicates) or treated with $4 \mathrm{nM}$ echinomycin at indicated time points (lower panel) ( $n=2$ replicates). Experiments were repeated 3 times. (D) Expression of MYC and HIF1 $\alpha$ target genes in H1944 cells treated with echinomycin at indicated concentrations for $24 \mathrm{~h}$ by qRT-PCR ( $n=3$ replicates). Experiments were repeated 2 times.

JQ1 is an inhibitor of BET bromodomain proteins and can transcriptionally inhibit the expression of MYC $[18,19,28]$. We tested the effect of JQ1 on H1944 cells. At $\mathrm{IC}_{50}$ of about $1 \mu \mathrm{M}$, JQ1 is much less potent than echinomycin $\left(\mathrm{IC}_{50}=3.9 \pm 1.1 \mathrm{nM}\right)$, and the lung cancer cells were more resistant to JQ1 than echinomycin as approximately $40 \%$ cells are still alive even after $48 \mathrm{~h}$ treatment by $20 \mu \mathrm{M}$ JQ1, while less than $20 \%$ viability was observed when the same cells received $4 \mathrm{nM}$ of echinomycin (Figure S5A). As expected, 
JQ1 transcriptionally inhibited the expression of myc (Figure S5C) leading to reduction of MYC protein (Figure S5B). In contrast to the effects of echinomycin, JQ1 had no effect on transcript but increased protein of HIF1 $\alpha$ (Figure S5B,C).

\subsection{Degradation of MYC and HIF1 $\alpha$ via Proteasome Dependent Pathways}

To test if echinomycin differentially affected MYC and HIF1 $\alpha$ proteins at different cellular localization, we compared cytosol, chromatin and nucleoplasm from vehicle and echinomycin-treated cells and evaluated the protein levels by western blot. As shown in Figure 2A, MYC was found primarily in chromatin where it was reduced by echinomycin treatment. HIF1 $\alpha$ was found in the chromatin, nucleoplasm and cytosol and its levels at all location were reduced by echinomycin. The fact chromatin-associated MYC and HIF1 $\alpha$ were reduced by echinomycin ruled out the possibility that inhibiting their binding to DNA contributes to their degradation.

To further characterize the degradation of chromatin-bound MYC and HIF1 $\alpha$ induced by echinomycin, we checked the kinetics of reduction in chromatin-bound MYC and HIF1 $\alpha$ proteins after being treated with cycloheximide (CHX), an inhibitor of protein synthesis, plus vehicle or $8 \mathrm{nM}$ echinomycin. The degradation of MYC and HIF1 $\alpha$ was faster in $\mathrm{CHX}$ plus echinomycin group than CHX plus vehicle group (Figure 2B). Consistent with the rapid turnover of HIF $1 \alpha$, its protein degradation was largely completed within $30 \mathrm{~min}$ after CHX treatment with the half-life $t_{1 / 2}=14.4 \mathrm{~min}$. However, the degradation is further accelerated by $4.5 \mathrm{~min}$ with the half-life of $9.9 \mathrm{~min}$ in cells that received echinomycin plus CHX. Similarly, echinomycin promoted the degradation of the MYC protein. Treatment of echinomycin decreased the half-life $\left(t_{1 / 2}\right)$ of MYC from $16.1 \mathrm{~min}$ to $11.2 \mathrm{~min}$.

To determine if echinomycin induced degradation of MYC and HIF $1 \alpha$ is by proteasomedependent pathway, we treated H1944 cells with $5 \mu \mathrm{M}$ MG132, a potent proteasomal inhibitor, with or without echinomycin. Echinomycin decreased protein level of MYC and HIF1 $\alpha$, and MG132 caused accumulation of both MYC and HIF1 $\alpha$ in a time-dependent manner (Figure 2C,D). However, concurrent treatment of MG132 with echinomycin abolished the effect of echinomycin on MYC and HIF1 $\alpha$ proteins, which indicates that echinomycin induced proteasome-dependent degradation of MYC and HIF1 $\alpha$. Together, these data indicate that echinomycin induced degradation of MYC and HIF1 $\alpha$ through proteasomal pathway other than through the regulation of mRNAs. 
A

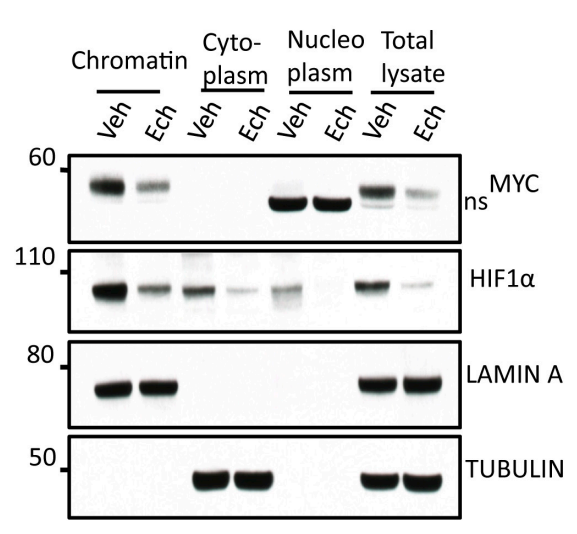

B

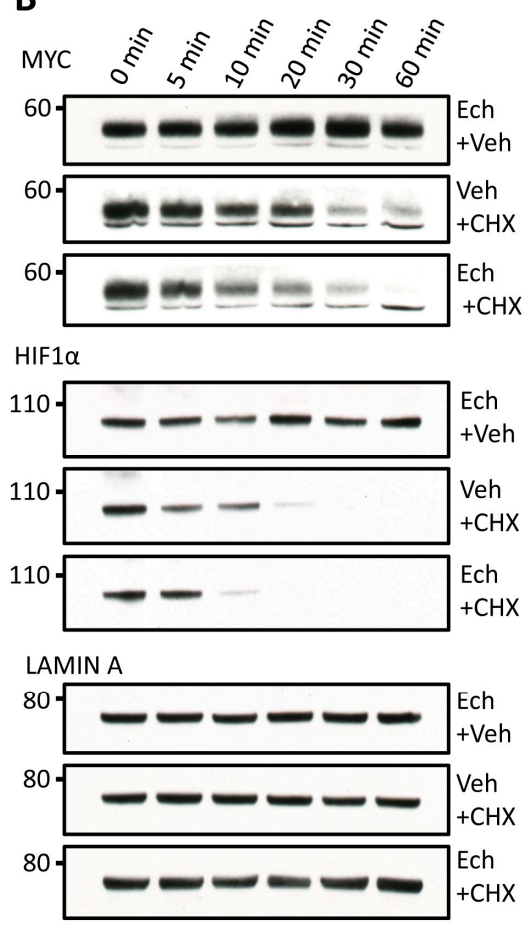

D
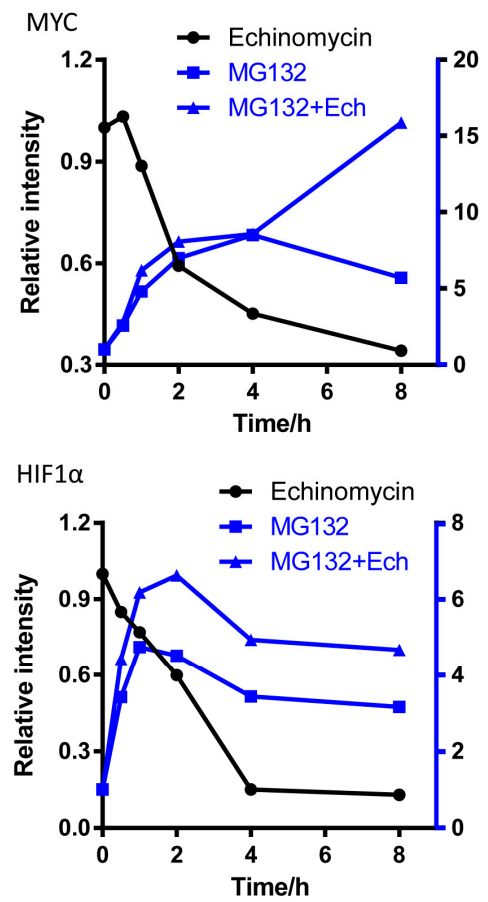

Figure 2. Induction of proteasomal degradation of MYC and HIF1 $\alpha$ by echinomycin. (A) MYC and HIF1 $\alpha$ in cytosol, nucleoplasm and chromatin in H1944 cells treated with $4 \mathrm{nM}$ echinomycin (Ech) or vehicle (Veh) for $24 \mathrm{~h}$ were analyzed by western blot after fractionation. Experiments were repeated 3 times. (B) Chromatin-bound MYC and HIF1 $\alpha$ in H1944 cells treated with echinomycin (Ech, $8 \mathrm{nM}$ ), cycloheximide ( $\mathrm{CHX}, 25 \mu \mathrm{g} / \mathrm{mL}$ ) or Ech + CHX for indicated time were checked by western blot. Experiments were repeated two times. (C) Quantification of MYC and HIF1 $\alpha$ in (B). (D) H1944 cells were treated with echinomycin (Ech, $8 \mathrm{nM})$, MG132 $(5 \mu \mathrm{M})$ or Ech + MG132 for indicated time, and MYC and HIF1 $\alpha$ proteins were analyzed by western blot. Experiments were repeated two times. Quantification of MYC and HIF1 $\alpha$ in (D). 


\section{3. $\beta$-TrCP and VHL Are Involved in the Degradation of MYC and HIF1 $\alpha$ Induced by} Echinomycin, Respectively

A number of proteins have been shown to regulate stability of MYC [29]. We reasoned that critical proteins responsible for echinomycin-induced HIF1 $\alpha$ and MYC degradation may be found among those that are regulated by echinomycin. Therefore, we tested levels of protein that had been implication in MYC degradation (Figure S6A) or stabilization (Figure S6B). Nuclear E3 ligases were also tested (Figure S6C). Among those possible candidates, we found $\beta$-TrCP was selectively reduced by echinomycin treatment (Figure S6B and Figure 3A,B). $\beta$-TrCP is an E3 ligase which can increase the stability of MYC by antagonizing SCF(Fbw7)-mediated turnover [30]. To test the role for $\beta$ - $\operatorname{TrCP}$ in echinomycin-induced MYC degradation, we infected H1944 cells with lentivirus carrying human $\beta$-TrCP. We found MYC degradation was inhibited in $\beta$-TrCP transduced cells (Figure $3 \mathrm{C}$ and Figure S7A,B). Thus, while only $25.4 \pm 2.6 \%$ MYC protein remained after $4 \mathrm{nM}$ echinomycin treatment in vector-transfected H1944 cells, $58.2 \pm 6.1 \%$ MYC remained in $\beta$-TrCP-transfected cells that received echinomycin (Figure 3C). Therefore, $\beta$ - $\operatorname{TrCP}$ can partially protect MYC from degradation induced by echinomycin, even though not completely. These data indicate that echinomycin induced the degradation of MYC by destabilizing MYC via decreasing $\beta$ - TrCP.
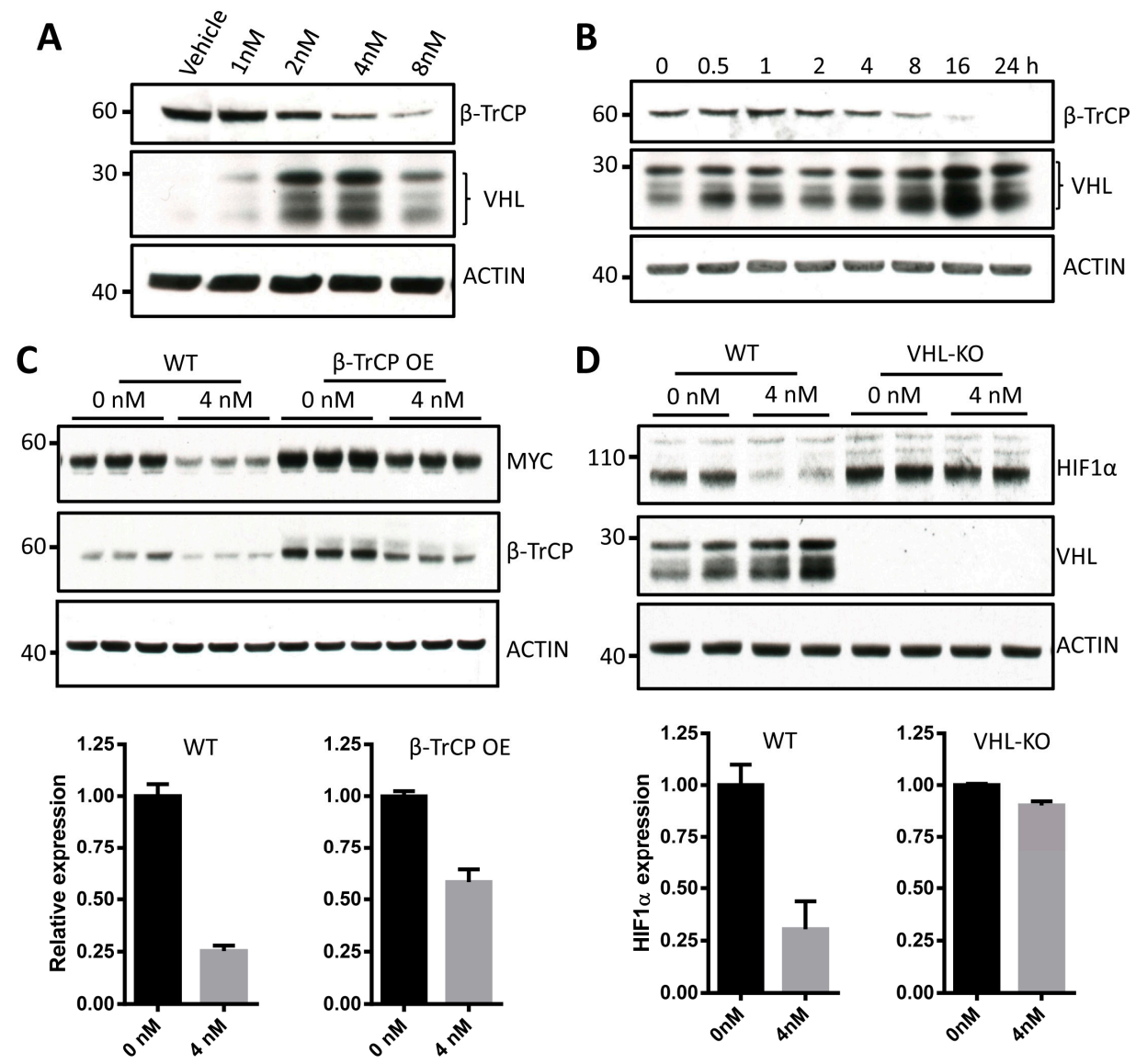

Figure 3. $\beta$-TrCP and VHL are involved in the degradation of MYC and HIF1 $\alpha$ induced by echinomycin, respectively. (A) Western blot analysis of $\beta$-TrCP and VHL proteins in H1944 lung adenocarcinoma cells treated with echinomycin at indicated concentrations for $24 \mathrm{~h}$. (B) Time-dependent response of $\beta$-TrCP and VHL proteins in $\mathrm{H} 1944$ cells treated with $4 \mathrm{nM}$ echinomycin at indicated time points. (C) Western blot and quantitative analysis of MYC in wild type H1944 cells and $\beta-\operatorname{TrCP}$ transduced H1944 cells treated with vehicle or $4 \mathrm{nM}$ echinomycin for $24 \mathrm{~h}$. (D) Western blot and quantitative analysis of HIF1 $\alpha$ in wild type H1944 cells and VHL deficient H1944 cells treated with vehicle or $4 \mathrm{nM}$ echinomycin for $24 \mathrm{~h}$. Experiments were repeated 2-3 times. 
Since von Hippel-Lindau protein (VHL) mediated pathway played a primary role in HIF1 $\alpha$ degradation [31], we tested if echinomycin affected VHL levels. Strikingly, we found the VHL increased after echinomycin treatment in a both dose- and time-dependent manner (Figure 3A,B). To investigate the direct role of VHL in HIF1 $\alpha$ degradation induced by echinomycin, we checked the response of HIF1 $\alpha$ to echinomycin in VHL knockout (VHLKO) H1944 cells generated by CRISPR-Cas9 genome editing technology (Figure S8A,B). As shown in Figure 3D and Figure S8C, VHL-KO cells were resistant to echinomycininduced HIF1 $\alpha$ degradation. These data demonstrated that VHL was responsible for the echinomycin-induced degradation of HIF1 $\alpha$.

To test whether these two degradation pathways are independent, we first examined the response of HIF1 $\alpha$ to echinomycin in $\beta$-TrCP OE H1944 cells. As shown in Figures S7 and S9A, in contrast to the degradation kinetics of MYC protein, the degradation of HIF1 $\alpha$ was similar in $\beta$-TrCP OE cells when compared with control cells. Likewise, the degradation of MYC was not abrogated in VHL-KO cells (Figure S9B). Therefore, the degradations of MYC and HIF1 $\alpha$ are independently regulated.

\subsection{Degradation of MYC and HIF1 $\alpha$ Induced by Echinomycin Is Independent of $p 53$ and LKB1}

Major portion of human cancers have defects or mutations in the p53 tumor-suppressor pathway, which has been implicated in the regulation of MYC and HIF1 $\alpha$ in tumor cells $[32,33]$. We therefore tested if the functions of echinomycin on MYC and HIF1 $\alpha$ are p53-dependent. We found that, in p53-null cells Calu- 1 lung cancer cells (Figure 4A), MYC and HIF1 $\alpha$ were effectively degraded following treatment with echinomycin. The degradation of MYC and HIF1 $\alpha$ showed a both dose- and time-dependent manner (Figure 4B,C). Consistent with the change of MYC and HIF1 $\alpha$, cell viability of Calu-1 showed a dose-dependent decrease when they were treated with echinomycin from $1 \mathrm{nM}$ to $8 \mathrm{nM}$ (Figure $4 \mathrm{~A}$ ). Therefore, the protein degradation of MYC and HIF1 $\alpha$ induced by echinomycin is p53-independent.

A

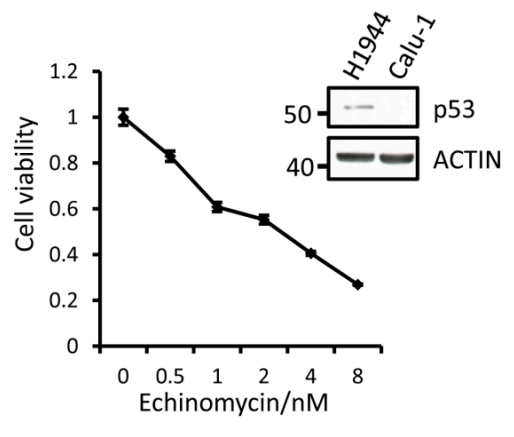

B

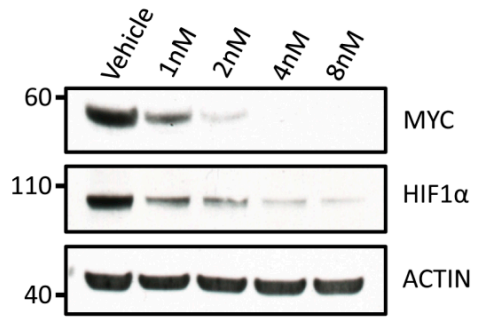

C

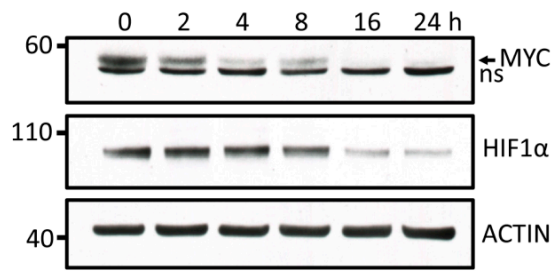

D
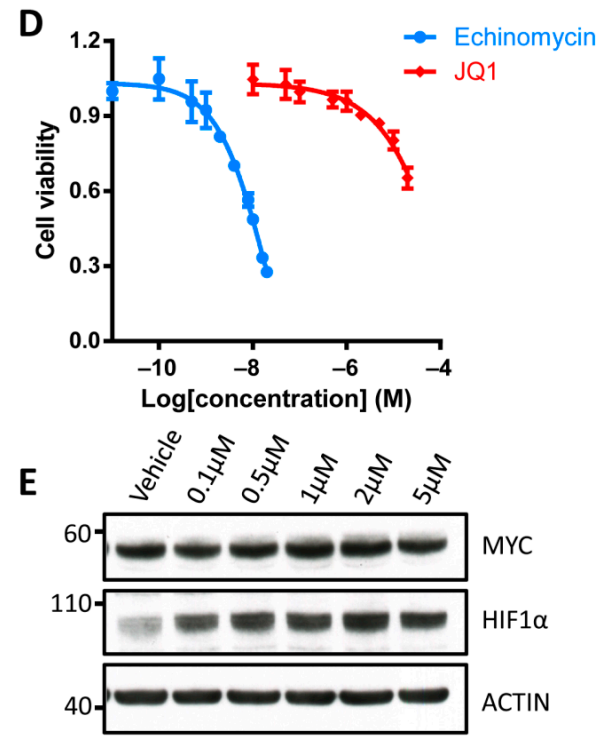

$\mathbf{F}$

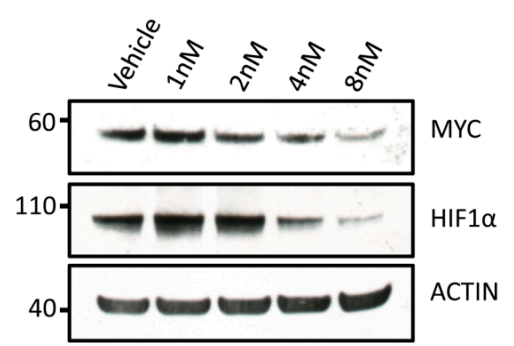

Figure 4. Degradation of MYC and HIF1 $\alpha$ induced by echinomycin is p53 and LKB1 independent. (A) Cell viability and proliferation assays by MTT in Calu-1 cells. Calu-1 cells were treated with 
echinomycin for $48 \mathrm{~h}$, and then cell viability and proliferation were checked by incubating with MTT overnight ( $n=3$ replicates). Insert shows the expression of p53 in H1944 and Calu-1 by western blot. (B,C) Protein levels of MYC and HIF1 $\alpha$ were analyzed in Calu-1 cells treated with different concentrations of echinomycin for $24 \mathrm{~h} \mathrm{(B)}$ or treated with $4 \mathrm{nM}$ echinomycin for indicated time (C). ns: non-specific band. Experiments were repeated three times. (D) MTT assay in A549 lung cancer cells. A549 cells were treated with either echinomycin or JQ1 for $48 \mathrm{~h}$ at indicated concentrations, and then cell viability was determined by MTT assay ( $n=3$ replicates). (E) Protein levels of MYC and HIF1 $\alpha$ in A549 cells were checked by western blot when treated with JQ1 at different concentrations. (F) MYC and HIF1 $\alpha$ proteins were checked by western blot in A549 cells which were treated by echinomycin for $24 \mathrm{~h}$ at indicated concentrations. Experiments were repeated two times.

Previous study reported JQ1 induced apoptosis in NSCLC cells of different genotypes through transcriptional repression of $m y c$, and that LKB1 mutation compromises sensitivity of these cells to JQ1 [34]. These data prompted us to test whether echinomycin also represses MYC by LKB1-dependent mechanisms. Since A549 cells harboring LKB1 mutation [34], they were highly resistant to the treatment of JQ1 as more than $60 \%$ cells survived even when they were treated with $20 \mu \mathrm{M}$ JQ1 for $48 \mathrm{~h}$ (Figure 4D). However, echinomycin effectively inhibited the growth and viability of these cells with $\mathrm{EC}_{50} \approx 9.5 \mathrm{nM}$ (Figure 4D). Consistent with previously reported data [34], JQ1 had no effect on the expression of MYC and perhaps induced the expression of HIF1 $\alpha$ in A549 cells (Figure 4E). In sharp contrast, both MYC and HIF1 $\alpha$ proteins were effectively degraded by echinomycin in A549 cells (Figure 4F). These results suggested that echinomycin may be used for the treatment of a broader range of cancers than JQ1 because echinomycin is effective regardless of p53 and LKB1 status.

\subsection{Therapeutic Effect of Echinomycin in Animal Models of Non-Small Cell Lung Cancer (NSCLC)}

To further investigate the antitumor effects of MYC and HIF1 $\alpha$ inhibition in vivo, we first explored xenograft model using H1944 cells which were originally from a non-small cell lung cancer patient. H1944 cells were injected into right flank of immunocompromised nude mice, and liposome formulated echinomycin [35] was administered subcutaneously near tumor on day 6 and day 14 at $200 \mu \mathrm{g} / \mathrm{kg}$. As shown in Figure 5A, H1944 tumors grew significantly slower in echinomycin-treated mice compared with vehicle treated controls, complete elimination of tumors were observed in 4 out of 12 mice (Figure 5A,B and Figure S10A,B). The average tumor volume was $70.93 \pm 28.12 \mathrm{~mm}^{3}$ in echinomycin treated group 32 days after tumor cell transplantation, which was about $22 \%$ of vehicle treated mice (320.1 $\pm 54.33 \mathrm{~mm}^{3}$ ) (Figure 5A). Consistent with these data, echinomycin effectively reduced tumor weight when compared with vehicle $(0.063 \pm 0.019 \mathrm{~g}$ in echinomcyin treated mice vs. $0.25 \pm 0.042 \mathrm{~g}$ in vehicle treated mice) on day 32 (Figure $5 \mathrm{~B}$ ). No gross toxicity was observed during the treatment, as there were no notable changes in body weight in echinomycin treated mice (Figure S10C).

In order to confirm inhibition of MYC and HIF1 $\alpha$ can inhibit the growth of lung cancer, we used mouse $\mathrm{Kras}^{\mathrm{G12D/+}} ; \mathrm{p53}^{-/-}$lung cancer cell line [36] for further validation. These cells also showed good response to echinomycin treatment at nanomolar concentration (Figure S11A). These cells had low expression of HIF1 $\alpha$, but with high expression of MYC (Figure S11B). It is striking that, when treated with $4 \mathrm{nM}$ echinomycin for $48 \mathrm{~h}, \mathrm{MYC}$ is almost gone (Figure S11B). When the tumor cells were transplanted into C57BL/6 via intravenous (IV) injection, they quickly formed metastatic lesions in the lung. Echinomycin remarkably inhibited the growth of tumors after three treatments by IV injection at the concentration of $250 \mu \mathrm{g} / \mathrm{kg}$ (Figure 5C,D). In vehicle-treated group, tumor cells formed lesions throughout the lung, while echinomycin-treated group significantly retarded the growth (Figure 5E). 
A

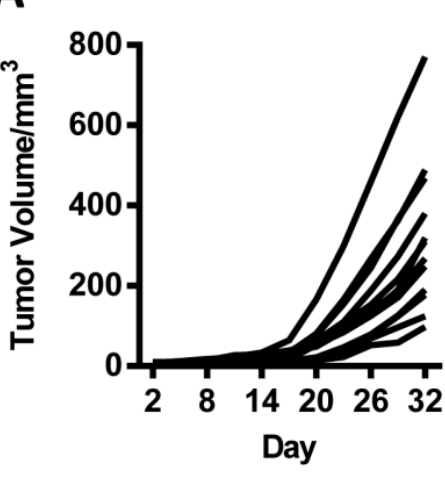

C
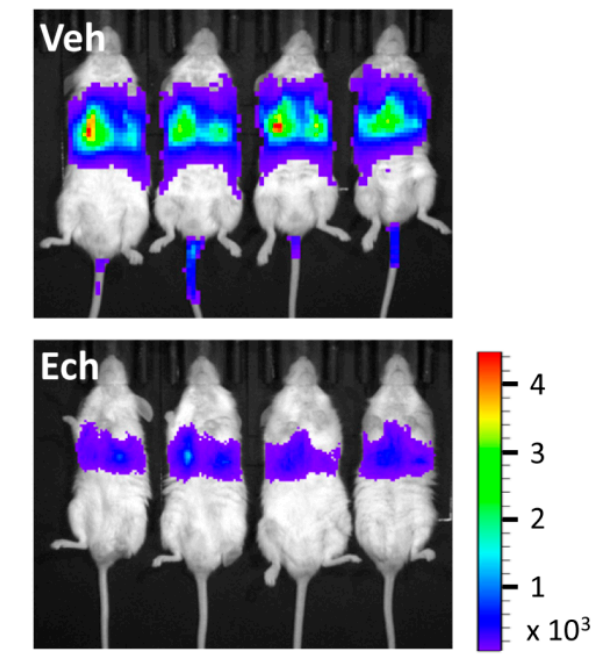

B
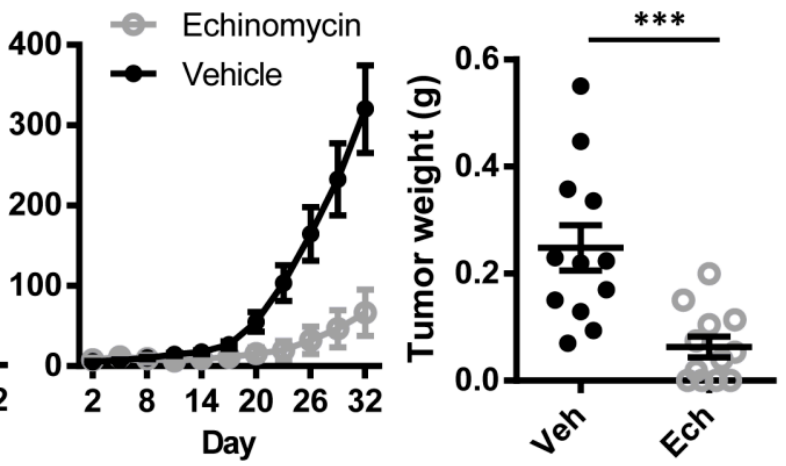

E
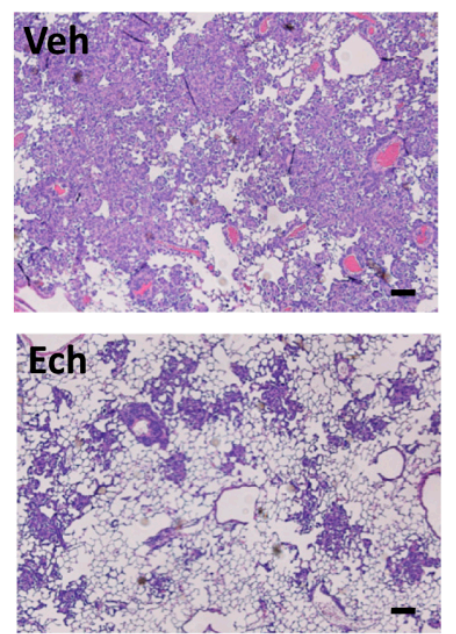

Figure 5. Targeting MYC and HIF1 $\alpha$ inhibited tumor growth in lung adenocarcinoma in xenograft mouse models. (A) Tumor growth of H1944 xenograft. H1944 cells $\left(1 \times 10^{6}\right)$ were injected s.c. into nude mice and treated with vehicle or echinomycin $(200 \mu \mathrm{g} / \mathrm{kg}$ ) on day 6 and day 13 after cell transplantation. Tumor volumes were determined by caliper measurements. Left panel: tumor volume of vehicle treated mice; Middle panel: tumor volume of echinomycin treated mice; Right panel: average tumor volume of vehicle and echinomycin treated mice. $\mathrm{n}=12$ mice/group. (B) Tumor weight was measured on day 32 after cell transplantation in vehicle and echinomycin treated H1944 xenograft mice. $n=12$ mice/group. ${ }^{* * *}, p=0.003$. (C) Representative images show the tumor cells in mice that received transplants of luciferase-expressing mouse $\mathrm{Kras}{ }^{\mathrm{G} 12 \mathrm{D} /+}$; $p 53^{-/-}$lung cancer cells in vehicle and echinomycin treated groups. (D) Quantification of bioluminescence count in (C). $n=6$ mice/group. ${ }^{* *}, p=0.002$. (E) $\mathrm{H} \&$ E staining shows the distribution of $\mathrm{Kras}{ }^{\mathrm{G} 12 \mathrm{D} /{ }^{+}} ; p 53^{-/-}$cancer cells in vehicle and echinomycin treated mouse lung tissues. Scale bar: $200 \mu \mathrm{m}$.

\subsection{Echinomycin Inhibits Growth of Eu-Myc Lymphoma}

Most aggressive B-cell lymphomas, such as Burkitt lymphoma, are characterized by dysregulation of the myc gene. We next tried to address if echinomycin could be applied for the therapy of lymphoma using E $\mu$-Myc mouse model of human Burkitt

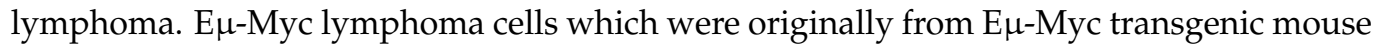
showed high sensitivity to echinomycin, with an $\mathrm{IC}_{50}$ of approximately $0.25 \mathrm{nM}$ (Figure 6A). Echinomycin down-regulated MYC and HIF1 $\alpha$ proteins despite increasing their mRNA

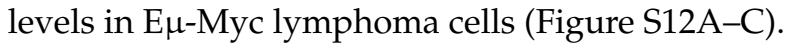




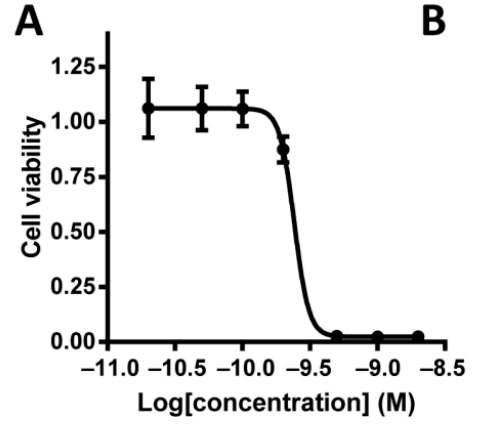

C

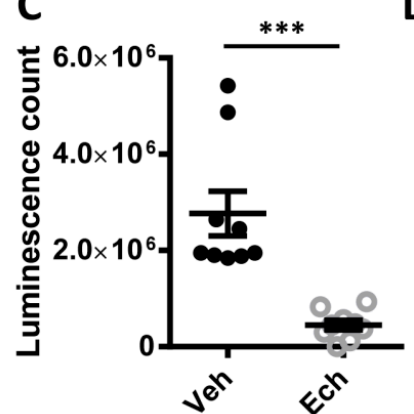

F
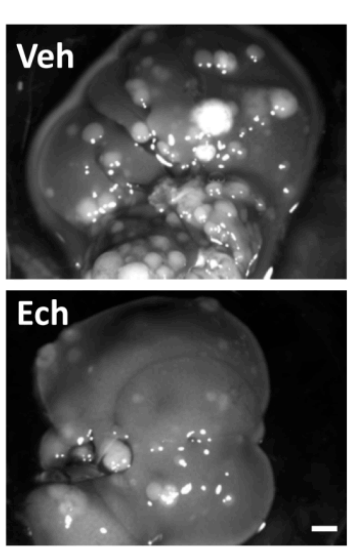

I

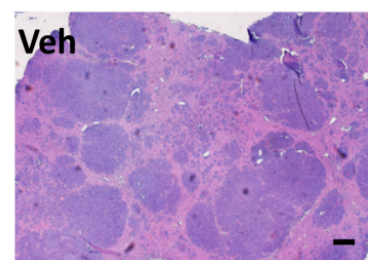

B

D

G
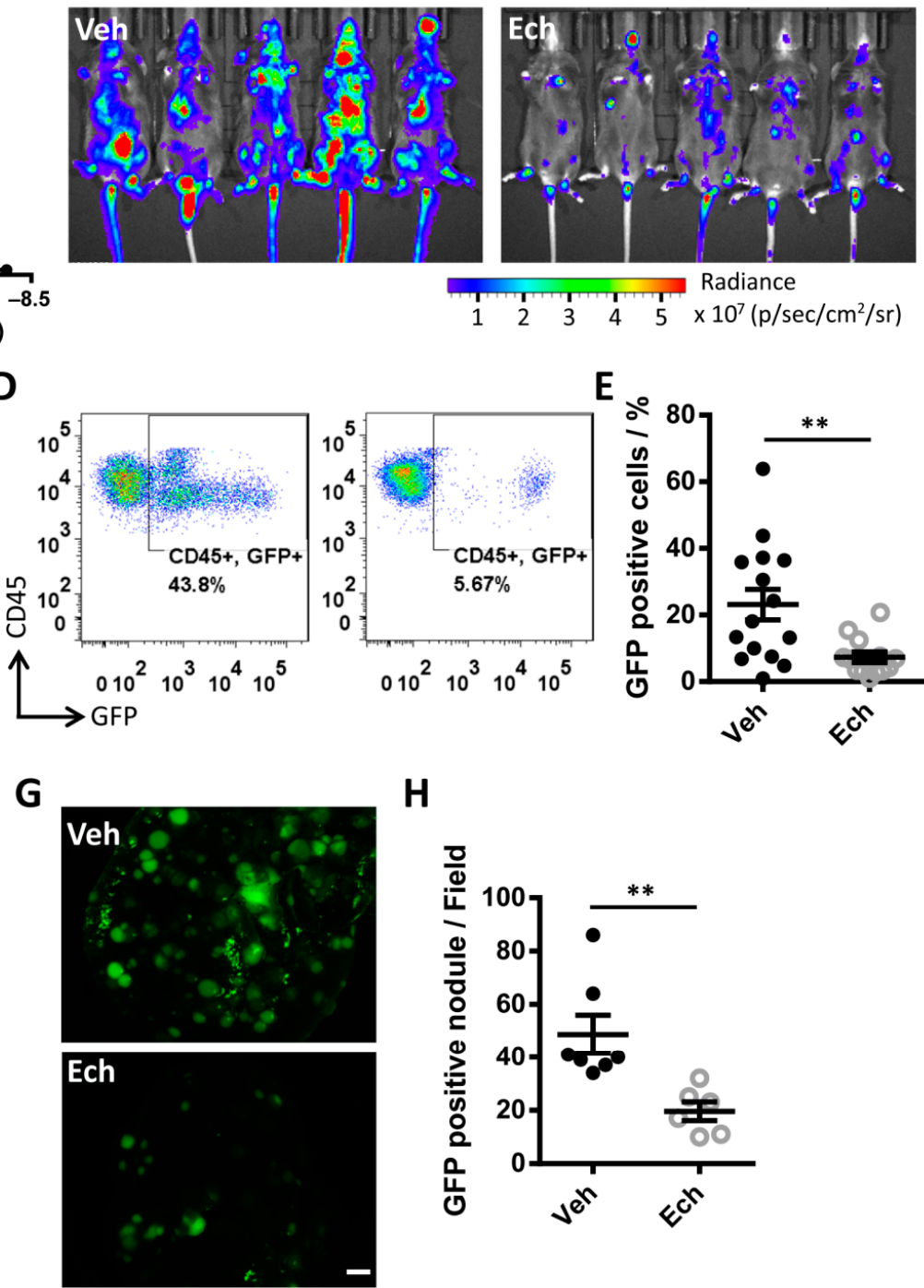

E

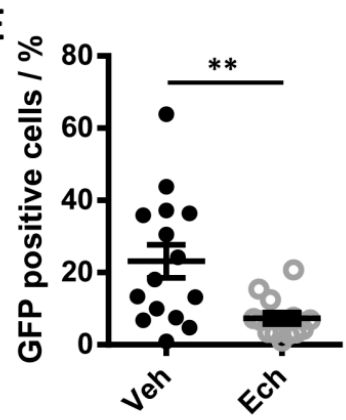

H

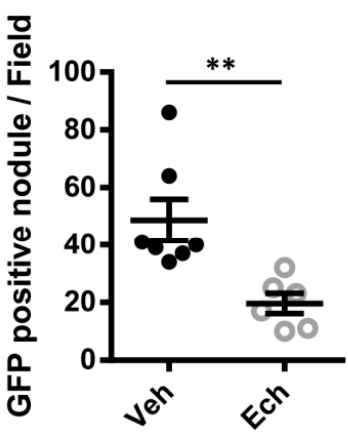

J
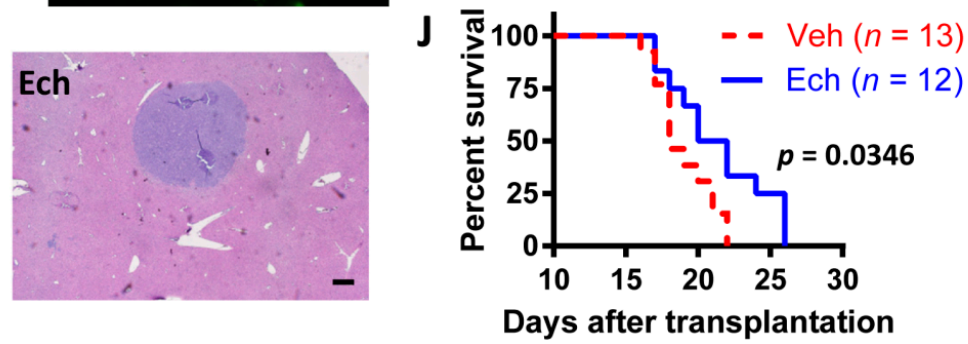

Figure 6. Inhibition of MYC and HIF1 $\alpha$ exhibited anticancer activity in E $\mu$-Myc B-cell lymphoma transplanted mouse model.(A) Growth inhibition curve of E $\mu$-Myc cells treated with echinomycin for $48 \mathrm{~h}$ at indicated concentrations $(n=4)$. (B) In vivo real-time bioluminescence imaging of luciferase-expressing E $\mu$-Myc lymphoma cells in vehicle and echinomycin treated mice. (C) Quantification of bioluminescence count in (B). $n=9$ mice/group. ${ }^{* * *}, p=0.0006$. (D,E) Representative images (D) and quantification results (E) showing GFP positive cells (lymphoma) in the blood in vehicle and echinomycin treated mice by flow cytometry. $n=15$ mice in Veh and 13 in Ech. ${ }^{* *}, p=0.005$. Experiments were repeated two times. Morphology of tumor nodules in liver were imaged under bright field $(\mathbf{F})$ and fluorescence $(\mathbf{G})$ in vehicle and echinomycin treated mice with E $\mu$-Myc cells transplant. Scale bar: $100 \mu \mathrm{m}$. (H) Quantification of GFP positive nodules in liver from (G). $n=7$ mice in Veh and 6 in Ech. ${ }^{* *}, p=0.001$. (I) H \& E staining shows the distribution and morphology of tumor nodules in vehicle and echinomycin treated mouse liver tissues. Scale bar: $200 \mu \mathrm{m}$. (J) Kaplan Meier survival curve of E $\mu-M y c$ lymphoma bearing mice treated with vehicle or echinomycin. $n=13$ mice in Veh and 12 in Ech. $p=0.0346$ by log-rank (Mantel-Cox) test. 
To determine the efficacy of echinomycin on preventing tumor progression, mice were inoculated with GFP-expressing E $\mu$-myc lymphoma cells and treated with echinomycin or vehicle control. Mice transplanted intravenously with lymphoma rapidly developed lymphomas and typically succumbed to the disease 3-4 weeks after transplantation. However, treatment of these mice with echinomycin resulted in a dramatic reduction of the tumor burden, as measured by bioluminescence in vivo (Figure 6B,C). We quantified the GFP expressing cells among peripheral blood leukocytes by flow cytometry. An average of $23.12 \pm 4.58 \% \mathrm{GFP}^{+}$cells in vehicle group and $7.31 \pm 1.59 \%$ in echinomycin treated mice were documented by flow cytometry (Figure 6D,E). Vehicle treated mice showed splenomegaly and enlarged liver, while echinomycin to some extent rescued these changes (Figure S13). Notably, we observed significantly less tumor nodules in liver in echinomycin treated mice than that in control group (Figure 6F-I). All these tumor bearing mice died within 22 days after transplantation in vehicle group, at which time point one third mice were still alive in echinomycin treated group, although all of them died within 26 days after transplantation. With these overall therapeutic benefits by echinomycin, drug treated mice showed prolonged survival when compared with control mice (Figure 6J).

\section{Discussion}

MYC and HIF1 $\alpha$ are critical in human cancer pathogenesis through regulation of metabolism, angiogenesis, cell proliferation and apoptosis, and self-renewal of cancer stem cells. Here we showed that echinomycin may be used to target their degradation for the purpose of cancer therapy. Our work presented herein makes three seminal points.

First, echinomycin causes degradation rather than blocking transcriptional activities of these oncoproteins. Previous result already showed echinomycin inhibited HIF1 $\alpha$ binding to the hypoxia-responsive element (HRE) DNA sequence of its target genes, and here we provided direct experimental evidence that echinomycin also inhibited DNA binding ability of MYC to E-box. However, the dose required to inhibit DNA binding is at least 10fold higher than their ability to inhibit MYC and HIF1 $\alpha$ function. These data prompted us to explore mechanism independent of inhibiting DNA-protein interaction. While previous studies have shown that echinomycin can reduce HIF1 $\alpha$ protein levels [37], it was not explored whether this was achieved through synthesis or degradation of HIF1 $\alpha$. Here, we addressed this question from the perspective of both RNA and protein levels. Our results clearly showed the mRNA of myc and hif $1 \alpha$ paradoxically increased while MYC and HIF $1 \alpha$ proteins decreased. Since the decrease is reversed by proteasome inhibitor, it must be achieved by proteasomal pathway. We further showed that echinomycin caused degradation of HIF1 $\alpha$ and MYC in a variety of cancer types tested here, including lung cancer, breast cancer, lymphoma and leukemia. These data suggest broad application of the drug in cancer therapy. A recent report showed echinomycin reduced the myc RNA in NB4 and Jurkat cells [38], which suggests that echinomycin may suppress MYC function by multiple mechanisms.

For traditionally non-druggable cancer targets, it is now desirable to target them for degradation through PROTAC [39]. However, such an approach requires structure-based design of chimera compound to binds target protein of as well as E3 ligase. Despite the strong interest, no PROTAC is available for either MYC or HIF1 $\alpha$ to our knowledge. Here, we empirically identified echinomycin as a non-PROTAC-based degrader for HIF1 $\alpha$ and MYC. Given the broad over-expression and biological significance of these oncogenes, echinomycin may emerge as an important tool for cancer therapy.

Second, echinomycin-induced degradation of HIF1 $\alpha$ and MYC is independent of p53 and LKB tumor suppressors. Recent studies suggested p53 is involved in the regulation of MYC and HIF1 $\alpha[32,33]$ and many anti-cancer drugs work in a p53-dependent manner. In the current study, our results demonstrated echinomycin effectively induced the degradation of MYC and HIF1 $\alpha$ and inhibited the growth of p53 deficient lung cancer cells, which suggests the function of echinomycin on MYC and HIF $1 \alpha$ is p53-independent and it can be used for the treatment of both p53 wild-type and mutated cancers. Myc can 
be transcriptionally regulated by BET bromodomain protein 4 (BRD4), and BET bromodomain inhibitor JQ1 selectively downregulates MYC and MYC-dependent target genes and showed anti-tumor effects of hematological malignancies and NSCLC $[18,19]$. However, some tumors are resistant to the treatment of JQ1, which has subsequently been revealed by the loss of LKB1 [34]. In contrast, echinomycin promoted the degradation of MYC regardless of LKB1 status. In addition, JQ1 can only be used for the treatment of tumors whose MYC expression is transcriptionally activated. However, echinomycin can be used for the tumors with highly expressed MYC as a result of enhanced transcription and/or protein stability. In addition, our data demonstrated that although JQ1 transcriptionally inhibited $m y c$, it stabilized HIF1 $\alpha$ protein without affecting its RNA level, which may limit its application to HIF driven solid tumors and blood malignancies. This may also alternatively explain why some tumor cells are resistant to the treatment of JQ1. In contrast, echinomycin can effectively induce the degradation of MYC and HIF1 $\alpha$, and inhibit their functions. Therefore, these functional features of echinomycin raised the intriguing possibility that echinomycin may be tested for a broad range of cancers regardless of the status of p53 and LKB1, and how MYC is over expressed.

Third, we showed that echinomycin induced HIF1 $\alpha$ degradation by causing overexpression of VHL. Since VHL is also involved in degradation of MDM2 [40] among other oncoproteins, it is possible that echinomycin can degrade MDM2. Likewise, degradation of MYC is hereby shown related to inhibition of $\beta$-TrCP expression, which was known to stabilize YAP [40] in addition to MYC. It would be of interest to test potential impact of echinomycin on the YAP oncoprotein, which represents another major undruggable oncoprotein [41].

\section{Conclusions}

In summary, our data demonstrated that MYC and HIF1 $\alpha$ protein were degraded through proteasome dependent pathways, by the $\beta$-TrCP- and VHL-dependent mechanisms, respectively, in echinomycin-treated cancer cells. In addition, administration of echinomycin inhibited growth of both lung adenocarcinoma xenograft and a syngeneic lymphoma model in mice. By showing that echinomycin simultaneously causing proteasomal degradation of MYC and HIF1 $\alpha$, our data provided a new approach to target these and potentially other oncogenic proteins for cancer therapy.

Supplementary Materials: The following are available online at https://www.mdpi.com/2072-6 694/13/4/694/s1, Table S1: qRT-PCR primers, Figure S1: Inhibition of DNA binding capacity of MYC and HIF1 $\alpha$ by echinomycin, Figure S2: Inhibition of cell growth and induction of apoptosis of lung cancer cells by echinomycin, Figure S3: Echinomycin increased mRNA level of myc and hif1 $\alpha$ in H1944 cells, Figure S4: Induced degradation of MYC and HIF1 $\alpha$ protein by echinomycin in lung, breast cancer and leukemia cells, Figure S5: Effect of bromodomain inhibitor JQ1 on MYC and HIF1 $\alpha$ in H1944 cells, Figure S6: Western blot analysis of proteins involved in the regulation of protein stability, Figure S7: Response to echinomycin of $\beta$ - TrCP overexpressed H1944 cells, Figure S8: VHL CRISPR in H1944 cells, Figure S9: The two signaling pathways controlling the degradation of MYC and HIF1 $\alpha$ are independent, Figure S10: H1944 lung adenocarcinoma xenograft model and toxicity analysis of echinomycin on mice in vivo, Figure S11: Response of mouse $\mathrm{Kras}{ }^{\mathrm{G} 12 \mathrm{D} /+} ; \mathrm{p5}^{-/-}$ lung cancer cells to echinomycin, Figure S12: Effect of echinomycin on MYC and HIF1 $\alpha$ in E $\mu-\mathrm{Myc}$ lymphoma cells, Figure S13: Morphologies of spleen and liver in E $\mu$-Myc lymphoma mice, Figure S14: The uncropped Western blots.

Author Contributions: X.H., P.Z., and Y.L. (Yang Liu) conceived the project and designed the research; X.H. performed research; X.H., P.Z., and Y.L. (Yang Liu) analyzed data; Y.L. (Yan Liu), C.B. and Y.W. provided technical help and echinomycin for in vitro and in vivo experiments; X.H. and Y.L. (Yang Liu) wrote the paper. All authors have read and agreed to the published version of the manuscript.

Funding: This work was supported by grants from NIH to Yang Liu and Pan Zheng (1U01 CA183030, R01 CA171972, and AI64350) and OncoImmune, Inc. 
Institutional Review Board Statement: The study was conducted according to the guidelines of the Declaration of Helsinki, and approved by the Institutional Review Board (or Ethics Committee) of Children's Research Institute at the Children's National Medical Center. All mouse experiments were conducted in accordance with standards of animal care and approved by the Children's National Medical Center (CNMC) Animal Care and Use Committee under the protocol "Molecular and cellular mechanism for immunity and cancer" (protocol code 00030363 and approved on 03/21/2013).

Informed Consent Statement: Not applicable.

Data Availability Statement: The data presented in this study are available on request from the corresponding author.

Acknowledgments: We thank Ricky W Johnstone and Leigh Ellis for kindly providing E $\mu$-myc lymphoma cells, and Tyler Jacks and Wen Xue for providing mouse Kras ${ }^{G 12 D /+} ; p^{-/-}$lung cancer cells. We also thank Wei Wu for helping draw the blood from mice for lymphoma analysis, Christopher Lazarski for sorting E $\mu$-Myc-GFP lymphoma cells and Xuexiang Du for discussing FACS experiments. Part of the study was performed when most authors were at the Children's National Medical Center.

Conflicts of Interest: Drs. Yang Liu and Pan Zheng are among the co-founders of, and have equity interest in OncoImmune, Inc. The remaining authors declare no competing financial interests.

\section{References}

1. Vita, M.; Henriksson, M. The Myc oncoprotein as a therapeutic target for human cancer. Semin. Cancer Biol. 2006, 16, 318-330. [CrossRef]

2. Li, Z.; Van Calcar, S.; Qu, C.; Cavenee, W.K.; Zhang, M.Q.; Ren, B. A global transcriptional regulatory role for c-Myc in Burkitt's lymphoma cells. Proc. Natl. Acad. Sci. USA 2003, 100, 8164-8169. [CrossRef] [PubMed]

3. Patel, J.H.; Loboda, A.P.; Showe, M.K.; Showe, L.C.; McMahon, S.B. Analysis of genomic targets reveals complex functions of MYC. Nat. Rev. Cancer 2004, 4, 562-568. [CrossRef] [PubMed]

4. Fernandez, P.C.; Frank, S.R.; Wang, L.; Schroeder, M.; Liu, S.; Greene, J.; Cocito, A.; Amati, B. Genomic targets of the human c-Myc protein. Genes Dev. 2003, 17, 1115-1129. [CrossRef]

5. Tansey, W.P. Mammalian MYC Proteins and Cancer. New J. Sci. 2014, 2014, 27. [CrossRef]

6. Gabay, M.; Li, Y.; Felsher, D.W. MYC activation is a hallmark of cancer initiation and maintenance. Cold Spring Harb. Perspect Med. 2014, 4. [CrossRef] [PubMed]

7. Oster, S.K.; Ho, C.S.; Soucie, E.L.; Penn, L.Z. The myc oncogene: MarvelouslY Complex. Adv. Cancer Res. 2002, $84,81-154$.

8. Podar, K.; Anderson, K.C. A therapeutic role for targeting c-Myc/Hif-1-dependent signaling pathways. Cell Cycle 2010, 9, 1722-1728. [CrossRef]

9. Dang, C.V.; Reddy, E.P.; Shokat, K.M.; Soucek, L. Drugging the 'undruggable' cancer targets. Nat. Rev. Cancer 2017, 17, 502. [CrossRef]

10. Wang, G.L.; Jiang, B.H.; Rue, E.A.; Semenza, G.L. Hypoxia-inducible factor 1 is a basic-helix-loop-helix-PAS heterodimer regulated by cellular O2 tension. Proc. Natl. Acad. Sci. USA 1995, 92, 5510-5514. [CrossRef]

11. Semenza, G.L. HIF-1 mediates metabolic responses to intratumoral hypoxia and oncogenic mutations. J. Clin. Investig. 2013, 123, 3664-3671. [CrossRef]

12. Jung, S.N.; Yang, W.K.; Kim, J.; Kim, H.S.; Kim, E.J.; Yun, H.; Park, H.; Kim, S.S.; Choe, W.; Kang, I.; et al. Reactive oxygen species stabilize hypoxia-inducible factor-1 alpha protein and stimulate transcriptional activity via AMP-activated protein kinase in DU145 human prostate cancer cells. Carcinogenesis 2008, 29, 713-721. [CrossRef] [PubMed]

13. Chua, Y.L.; Dufour, E.; Dassa, E.P.; Rustin, P.; Jacobs, H.T.; Taylor, C.T.; Hagen, T. Stabilization of hypoxia-inducible factor1alpha protein in hypoxia occurs independently of mitochondrial reactive oxygen species production. J. Biol. Chem. 2010, 285, 31277-31284. [CrossRef]

14. Baba, Y.; Nosho, K.; Shima, K.; Irahara, N.; Chan, A.T.; Meyerhardt, J.A.; Chung, D.C.; Giovannucci, E.L.; Fuchs, C.S.; Ogino, S. HIF1A overexpression is associated with poor prognosis in a cohort of 731 colorectal cancers. Am. J. Pathol. 2010, 176, $2292-2301$. [CrossRef] [PubMed]

15. Liu, B.; Liu, Q.; Song, Y.; Li, X.; Wang, Y.; Wan, S.; Zhang, Z.; Su, H. Polymorphisms of HIF1A gene are associated with prognosis of early stage non-small-cell lung cancer patients after surgery. Med. Oncol. 2014, 31, 877. [CrossRef]

16. Hoffmann, A.C.; Mori, R.; Vallbohmer, D.; Brabender, J.; Klein, E.; Drebber, U.; Baldus, S.E.; Cooc, J.; Azuma, M.; Metzger, R.; et al. High expression of HIF1a is a predictor of clinical outcome in patients with pancreatic ductal adenocarcinomas and correlated to PDGFA, VEGF, and bFGF. Neoplasia 2008, 10, 674-679. [CrossRef] [PubMed]

17. Semenza, G.L. Targeting HIF-1 for cancer therapy. Nat. Rev. Cancer 2003, 3, 721-732. [CrossRef]

18. Mertz, J.A.; Conery, A.R.; Bryant, B.M.; Sandy, P.; Balasubramanian, S.; Mele, D.A.; Bergeron, L.; Sims, R.J., 3rd. Targeting MYC dependence in cancer by inhibiting BET bromodomains. Proc. Natl. Acad. Sci. USA 2011, 108, 16669-16674. [CrossRef]

19. Delmore, J.E.; Issa, G.C.; Lemieux, M.E.; Rahl, P.B.; Shi, J.; Jacobs, H.M.; Kastritis, E.; Gilpatrick, T.; Paranal, R.M.; Qi, J.; et al. BET bromodomain inhibition as a therapeutic strategy to target c-Myc. Cell 2011, 146, 904-917. [CrossRef] [PubMed] 
20. Kim, J.W.; Gao, P.; Liu, Y.C.; Semenza, G.L.; Dang, C.V. Hypoxia-inducible factor 1 and dysregulated c-Myc cooperatively induce vascular endothelial growth factor and metabolic switches hexokinase 2 and pyruvate dehydrogenase kinase 1. Mol. Cell Biol. 2007, 27, 7381-7393. [CrossRef] [PubMed]

21. Zhang, J.; Sattler, M.; Tonon, G.; Grabher, C.; Lababidi, S.; Zimmerhackl, A.; Raab, M.S.; Vallet, S.; Zhou, Y.; Cartron, M.A.; et al. Targeting angiogenesis via a c-Myc/hypoxia-inducible factor-1alpha-dependent pathway in multiple myeloma. Cancer Res. 2009, 69, 5082-5090. [CrossRef]

22. Malchenko, S.; Sredni, S.T.; Bi, Y.; Margaryan, N.V.; Boyineni, J.; Mohanam, I.; Tomita, T.; Davuluri, R.V.; Soares, M.B. Stabilization of HIF-1alpha and HIF-2alpha, up-regulation of MYCC and accumulation of stabilized p53 constitute hallmarks of CNS-PNET animal model. PLoS ONE 2017, 12, e0173106. [CrossRef] [PubMed]

23. Kong, D.; Park, E.J.; Stephen, A.G.; Calvani, M.; Cardellina, J.H.; Monks, A.; Fisher, R.J.; Shoemaker, R.H.; Melillo, G. Echinomycin, a small-molecule inhibitor of hypoxia-inducible factor-1 DNA-binding activity. Cancer Res. 2005, 65, 9047-9055. [CrossRef]

24. Vlaminck, B.; Toffoli, S.; Ghislain, B.; Demazy, C.; Raes, M.; Michiels, C. Dual effect of echinomycin on hypoxia-inducible factor-1 activity under normoxic and hypoxic conditions. FEBS J. 2007, 274, 5533-5542. [CrossRef] [PubMed]

25. Takakura, M.; Kyo, S.; Kanaya, T.; Hirano, H.; Takeda, J.; Yutsudo, M.; Inoue, M. Cloning of human telomerase catalytic subunit (hTERT) gene promoter and identification of proximal core promoter sequences essential for transcriptional activation in immortalized and cancer cells. Cancer Res. 1999, 59, 551-557.

26. Mendez, J.; Stillman, B. Chromatin association of human origin recognition complex, cdc6, and minichromosome maintenance proteins during the cell cycle: Assembly of prereplication complexes in late mitosis. Mol. Cell. Biol. 2000, 20, 8602-8612. [CrossRef]

27. Lasorsa, E.; Smonksey, M.; Kirk, J.S.; Rosario, S.; Hernandez-Ilizaliturri, F.J.; Ellis, L. Mitochondrial protection impairs BET bromodomain inhibitor-mediated cell death and provides rationale for combination therapeutic strategies. Cell Death Dis. 2015, 6, e2014. [CrossRef] [PubMed]

28. Zuber, J.; Shi, J.; Wang, E.; Rappaport, A.R.; Herrmann, H.; Sison, E.A.; Magoon, D.; Qi, J.; Blatt, K.; Wunderlich, M.; et al. RNAi screen identifies Brd4 as a therapeutic target in acute myeloid leukaemia. Nature 2011, 478, 524-528. [CrossRef]

29. Farrell, A.S.; Sears, R.C. MYC degradation. Cold Spring Harb. Perspect Med. 2014, 4. [CrossRef]

30. Popov, N.; Schulein, C.; Jaenicke, L.A.; Eilers, M. Ubiquitylation of the amino terminus of Myc by SCF(beta-TrCP) antagonizes SCF(Fbw7)-mediated turnover. Nat. Cell Biol. 2010, 12, 973-981. [CrossRef]

31. Masoud, G.N.; Li, W. HIF-1alpha pathway: Role, regulation and intervention for cancer therapy. Acta Pharm. Sin. B 2015, 5, 378-389. [CrossRef]

32. Sachdeva, M.; Zhu, S.; Wu, F.; Wu, H.; Walia, V.; Kumar, S.; Elble, R.; Watabe, K.; Mo, Y.Y. p53 represses c-Myc through induction of the tumor suppressor miR-145. Proc. Natl. Acad. Sci. USA 2009, 106, 3207-3212. [CrossRef] [PubMed]

33. Yang, J.; Ahmed, A.; Poon, E.; Perusinghe, N.; de Haven Brandon, A.; Box, G.; Valenti, M.; Eccles, S.; Rouschop, K.; Wouters, B.; et al. Small-molecule activation of p53 blocks hypoxia-inducible factor 1alpha and vascular endothelial growth factor expression in vivo and leads to tumor cell apoptosis in normoxia and hypoxia. Mol. Cell. Biol. 2009, 29, 2243-2253. [CrossRef] [PubMed]

34. Shimamura, T.; Chen, Z.; Soucheray, M.; Carretero, J.; Kikuchi, E.; Tchaicha, J.H.; Gao, Y.; Cheng, K.A.; Cohoon, T.J.; Qi, J.; et al. Efficacy of BET bromodomain inhibition in Kras-mutant non-small cell lung cancer. Clin. Cancer Res. Off. J. Am. Assoc. Cancer Res. 2013, 19, 6183-6192. [CrossRef] [PubMed]

35. Bailey, C.M.; Liu, Y.; Peng, G.; Zhang, H.; He, M.; Sun, D.; Zheng, P.; Liu, Y.; Wang, Y. Liposomal formulation of HIF-1alpha inhibitor echinomycin eliminates established metastases of triple-negative breast cancer. Nanomedicine 2020, 29, 102278. [CrossRef]

36. Xue, W.; Dahlman, J.E.; Tammela, T.; Khan, O.F.; Sood, S.; Dave, A.; Cai, W.; Chirino, L.M.; Yang, G.R.; Bronson, R.; et al. Small RNA combination therapy for lung cancer. Proc. Natl. Acad. Sci. USA 2014, 111, E3553-E3561. [CrossRef]

37. Widmer, D.S.; Hoek, K.S.; Cheng, P.F.; Eichhoff, O.M.; Biedermann, T.; Raaijmakers, M.I.; Hemmi, S.; Dummer, R.; Levesque, M.P. Hypoxia contributes to melanoma heterogeneity by triggering HIF1alpha-dependent phenotype switching. J. Investig. Dermatol. 2013, 133, 2436-2443. [CrossRef]

38. Yonekura, S.; Itoh, M.; Okuhashi, Y.; Takahashi, Y.; Ono, A.; Nara, N.; Tohda, S. Effects of the HIF1 inhibitor, echinomycin, on growth and NOTCH signalling in leukaemia cells. Anticancer Res. 2013, 33, 3099-3103.

39. Salami, J.; Crews, C.M. Waste disposal-An attractive strategy for cancer therapy. Science 2017, 355, 1163-1167. [CrossRef]

40. Roe, J.S.; Youn, H.D. The positive regulation of p53 by the tumor suppressor VHL. Cell Cycle 2006, 5, 2054-2056. [CrossRef] [PubMed]

41. Ma, S.; Meng, Z.; Chen, R.; Guan, K.L. The Hippo Pathway: Biology and Pathophysiology. Annu. Rev. Biochem. 2019, 88, 577-604. [CrossRef] [PubMed] 